\title{
Political views on a further deregulation of the European road haulage market
}

\author{
Stephan Keuchel ${ }^{1 *}$, Thomas Beckschwarte ${ }^{1}$ and Fabian Ernst ${ }^{2}$
}

\author{
* Correspondence: stephan. \\ keuchel@w-hs.de \\ ${ }^{1}$ Westphalian University of Applied \\ Sciences, August-Schmidt-Ring 10, \\ 45665 Recklinghausen, Germany \\ Full list of author information is \\ available at the end of the article
}

\begin{abstract}
Within the broad ongoing review of the legislation of the European road haulage market the European Commission presented in May 2017 several proposals to clarify the regulation of the market, especially market access, driving and rest periods, and the application of the posted workers directive. The paper aims to show economic implications of the suggested regulation on the basis of two round trip models and to outline the differences of political and regional interests by analysing the ammendments to the proposals handed in by members of the political groups of the different Member States.

The proposed regulation can be viewed as a further deregulation of the market with further shifts of markets shares in international and cabotage markets. This in turn is reflected by distinct regional differences of amendments of members within the different political groups.
\end{abstract}

Keywords: European transport policy, Road haulage market, Deregulation, Cabotage, Posting of workers, Interest groups, Policy process

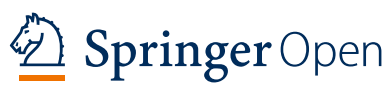

\section{Introduction}

In the first approach to liberalise the European road haulage sector as from 1993 a price- and quantity-regulated market was opened whereas in the second approach as from 2004 this liberalised market has been enlarged. Though, there were restrictions to cabotage until 2009. As from 2009 cabotage operations have been restricted to three cabotage operations after an incoming international transport operation (Koliousis, I. (2016)). Due to the first approach there were productivity gains and harmonised tax regulations whereas due to the second approach most of the cost cuttings stem from the substantial wage differences between drivers in the new and old Member States.

Within the broad ongoing review of the legislation of the European road haulage market the European Commission presented in May 2017 several proposals to clarify the regulation of the market, especially market access, driving and rest periods, and the application of the posted workers directive. The purpose has been to improve efficiency by means of avoiding empty runs, less administrational burden, and more flexibility to organise round trips. On the other hand, there is an ongoing debate on unfair

(c) The Author(s). 2020 Open Access This article is licensed under a Creative Commons Attribution 4.0 International License, which permits use, sharing, adaptation, distribution and reproduction in any medium or format, as long as you give appropriate credit to the original author(s) and the source, provide a link to the Creative Commons licence, and indicate if changes were made. The images or other third party material in this article are included in the article's Creative Commons licence, unless indicated otherwise in a credit line to the material. If material is not included in the article's Creative Commons licence and your intended use is not permitted by statutory regulation or exceeds the permitted use, you will need to obtain permission directly from the copyright holder. To view a copy of this licence, visit http://creativecommons.org/licenses/by/4.0/. 
competition due to substantial wage differences between drivers of different European Member States and the working conditions of drivers.

The purpose of this paper is to analyse economic consequences of the proposals of the European Commission and to provide an overview of the different positions of Members of the European Parliament.

To this end the paper is organised as follows. In chapter 2 the major ideas of the proposals the European Commission provided in May 2017 in terms of market access, rest period regulation, and application of the Posting of Workers Directive are described. In chapter 3 a round trip model including cabotage operations and an international round trip model are presented based on the existing regulation. Economic consequences of the proposals of the EU Commission are derived. Against this background the development of road haulage markets is described with a focus on Poland, Germany, and France. In chapter 4 results of a content analysis of the amendments to the proposals of members of the responsible committee differentiated by political groups and regions are presented in order to outline the scope of political and regional interests. In chapter 5 economic implications of a further deregulation of the road haulage market and political and regional interests are summarised and some conclusions drawn.

\section{Policy context}

The legislation discussed here is part of a broad ongoing review of the EU road transport legislation aiming at a clean, competitive, and connected mobility. According to Article 17(3) of Regulation (EC) No 1072/2009 on access to the international road haulage market the European Commission (2014) reported on the state of the road haulage market to the European Parliament and the Council. The market volume at the time was still recovering from the major economic crisis in 2008. Market volumes today actually reach before crisis levels. One of the major economic concerns for further opening of road haulage markets was related to the productivity in the market. According to the report productivity in international transport is substantially higher compared with national transport. Empty runs accounted for about $10 \%$ of the vehicle kilometers in bilateral international transport as well as cross-trade. In national transport the share of empty runs appears to be higher, around $25 \%$. Due to imbalances in transport flows and logistics operations a certain degree of empty runs is an unavoidable part of road haulage. Since opportunity costs increase with distance a lower degree of empty runs in international transport seems to be reasonable. Though cabotage operations appeared to have a substantial higher share of empty runs compared with national transport operations. Before the clarification of the cabotage regulation in 2009 (Regulation (EC) No 1072/2009) the share of empty runs of cabotage operations was reported as high as $75 \%$ with trucks registered in the Member States which entered the European Union as from 2004 compared with 55\% with trucks registered in the old Member States. With the new regulation specific national rules for cabotage disappeared (Steer Davies Gleave (2013)). It can be assumed that due to the new regulation quite a few hindrances of cabotage were abolished which not only has led to an increase in cabotage but also to a decrease in empty runs. As from 2009 a continuous decrease of empty runs has been observed for both, cabotage with trucks registered in new Member States down to 52\% and cabotage with trucks registered in old Member States down to below 45\% in 2012. 
It seems that the shares of empty runs are decreasing and converging (European Commission (2014)).

Further decreasing empty runs and increasing productivity in the European road haulage market was one of the major economic issues of the first Mobility Package proposed in May 2017. Three proposals were made by the EU Commission in order to amend the regulation of the access to the international road transport market (Regulation (EC) No 1072/2009) (European Commission (2017b)) and to amend the regulation of the social conditions in the road haulage market. Proposals for the latter refer to Regulation (EC) 561/2006 as regards driving times and rest periods (European Commission (2017c)) and to Directive 2006/22/EC laying down specific rules especially for the payment of drivers with respect to the posted workers directive (Directive 96/71/ EC and Directive 2014/67/EU) (European Commission (2017a)).

At the time being access to the international road transport market is not restricted for a company registered in a Member State holding a community license. But cabotage is restricted according to Regulation (EC) No 1072/2009, Art. 8. In order to avoid empty runs road hauliers are entitled to conduct three cabotage operations following an incoming international carriage within 7 days. There arose several questions hindering the enforcement of that regulation, especially the time of the end of the incoming carriage and the number of loadings and unloadings within one cabotage operation. In order to ease the administrational burden of enforcement for both hauliers and authorities this regulation is proposed to be changed to unlimited cabotage operations within 5 days after the incoming international carriage.

Closely related to the regulation of market access is the proposal for a change in the breaks as well as daily and weekly rest periods (Regulation (EC) 561/2006). The proposal aims at enhancing the flexibility for operators while allowing transport workers to retain adequate rest periods and favouring the possibility to have this rest at home or in an adequate accommodation. The proposed amendments of article 8 of the regulation especially extend the period for arranging weekly rest periods from two to 4 weeks. Drivers can have four regular weekly rest periods of at least $45 \mathrm{~h}$ or a combination of regular weekly rest periods and up to two reduced weekly rest periods of at least $24 \mathrm{~h}$. This would allow two consecutive reduced rest periods. The reduced weekly rest periods have to be compensated en bloc before the end of the third week.

Further, the proposal for a directive amending Directive 2006/22EC lays down specific rules with respect to Directive 96/71/EC and the enforcement Directive 2014/67/ EU for posting drivers in the road transport sector. In Article 2 it is suggested that Member States shall not apply the regulation of minimum paid annual holidays nor the minimum rates of pay, including overtime rates, to drivers performing international carriage operations as defined by Regulation 1072/2009 when the period of posting to their territory to perform these operations is shorter than or equal to 3 days during a period of one calendar month. Otherwise the above mentioned payment regulation has to be applied for the entire period of posting during that month. The time threshold is meant to ease the administrational burden of the companies conducting international carriage operations in some Member States on an occasional basis. The time threshold does not apply to cabotage operations meaning that minimum paid annual leave and minimum rate of pay of the host Member State applies irrespective of the frequency and duration of the operations carried out by the driver. 
The time threshold regulation of the application of minimum rates of pay in international carriage operations would clarify the different opinions on this matter between the EU Commission and the three Member States France, Germany, and Austria. Their engagement to apply their minimum wage regulations for international carriage operations in general has led to infringement procedures against these countries since this general application is assumed to hinder the internal market from functioning properly.

\section{Market development} Cabotage

The economic consequences of the proposals of the EU Commission for a new regulation of the European road haulage market can be analysed by means of a round trip model based on the existing regulation as a reference. The model is contextualised to a road haulage company established in Poland. This can also be a subsidiary company of a road haulage company established for example in Germany.

According to Article 3 of Directive 2002/85/EC Member States shall take the necessary measure to ensure that motor vehicles of categories N2 and N3 may be used on the road only if equipped with a speed limitation device set in such a way that their speed cannot exceed $90 \mathrm{~km} / \mathrm{h}$. (European Parliament and Council of the European Union (2002)) on average this speed is somewhat lower. This can be due to speed limitations below $90 \mathrm{~km} / \mathrm{h}$. Further, the longer a trip lasts the more likely it is that the speed is reduced due to delays caused by heavy traffic or due to construction sites. The shorter the trips the higher is the share of rural and urban roads used to reach the motorway and to reach the destination from the motorway, respectively. In large urban areas average speed is reduced to less than $30 \mathrm{~km} / \mathrm{h}$ during morning and or afternoon peak hours even on major roads. Therefore, an average speed of $60 \mathrm{~km} / \mathrm{h}$ is assumed to calculate the driving times of the round trip. (INRIX, 2018).

The origin of the round trip is Warsaw where the truck is loaded on Monday from 9 am to $10 \mathrm{am}$ for an international transport operation to the Port of Hamburg. With an average speed of $60 \mathrm{~km} / \mathrm{h}$ the driver needs around $14 \mathrm{~h}$ of driving for the $850 \mathrm{~km}$, that is $9 \mathrm{~h}$ driving time on Monday, a break of $45 \mathrm{~min}, 11 \mathrm{~h}$ daily rest period, and another 5 $\mathrm{h}$ of driving on Tuesday morning. The truck can be unloaded and, since this is a best case scenario, loaded again by $3 \mathrm{pm}$ with a payload to Cologne. For the $430 \mathrm{~km}$ of this cabotage operation the driver needs around $7 \mathrm{~h}$ of driving, interrupted by two breaks and a daily rest period of $11 \mathrm{~h}$, and arrives in at the destination on Wednesday $8 \mathrm{am}$. Unloading and loading for a second cabotage operation takes $2 \mathrm{~h}$. Therefore, the driver can head back to Hamburg at 10 am and will arrive at the destination at Thursday, 6 am. Unloading and loading for a third cabotage operation to Berlin takes $2 \mathrm{~h}$. After $290 \mathrm{~km} 5 \mathrm{~h}$ of driving and a break of $45 \mathrm{~min}$ the driver will arrive at the destination at $2 \mathrm{pm}$. After $2 \mathrm{~h}$ he has loaded another payload, in this case for an international transport operation back to Warsaw. For the $570 \mathrm{~km}$ distance he needs another $9.5 \mathrm{~h}$ of driving and a daily rest period of $11 \mathrm{~h}$. He will arrive in Warsaw at midday and has unloaded before $2 \mathrm{pm}$, and can spend his regular weekly rest period.

Summarising, the truck driver made it within 5 days from Warsaw via Hamburg, conducted three cabotage trips and headed back to the origin of the round trip. Instead of heading back to Warsaw after three cabotage operations, the driver can continue with a 


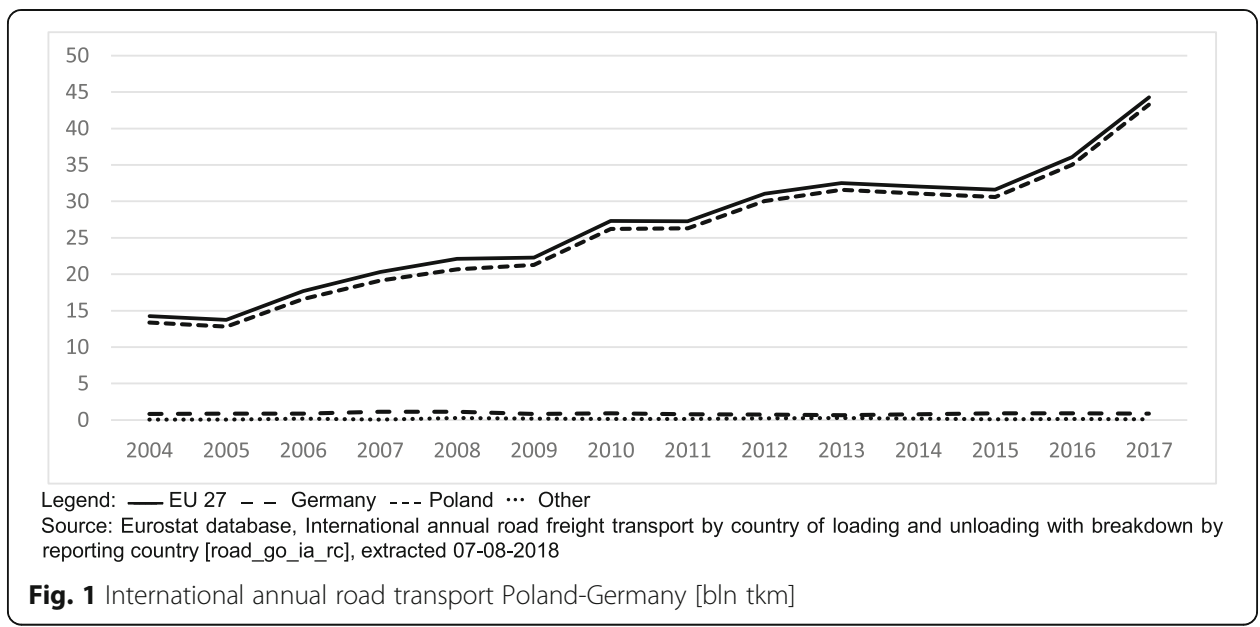

payload to a destination in France and subsequently conduct cabotage operations before returning to Poland or return to Germany in order to conduct cabotage operations in Germany again. The optional reduced weekly rest period gives some flexibility to organise this round trip within 2 weeks (AECOM (2014)).

Figure 1 shows the international annual transport between Poland and Germany differentiated by the Member States the trucks are registered in. Since the costs of operating a truck are substantially lower in Poland, especially due to the lower wages of the drivers, the market share of the in Poland registered trucks is above 90\%. (Eurostat database (2018b)).

Figure 2 displays shares of cabotage operations in Germany differentiated by trucks registered in western European Member States and eastern European Member States. There is a clear tendency of increasing cabotage operations. Cabotage operations with trucks registered in Western European Countries are slightly decreasing whereas there is a steady increase of cabotage operations operated with trucks registered in eastern European Member States. This holds especially for trucks registered in Poland which are, therefore, separately displayed. (Eurostat database (2018c)).

Figure 3 shows the international annual transport between France and Germany differentiated by the Member States the trucks are registered in. The declining shares of

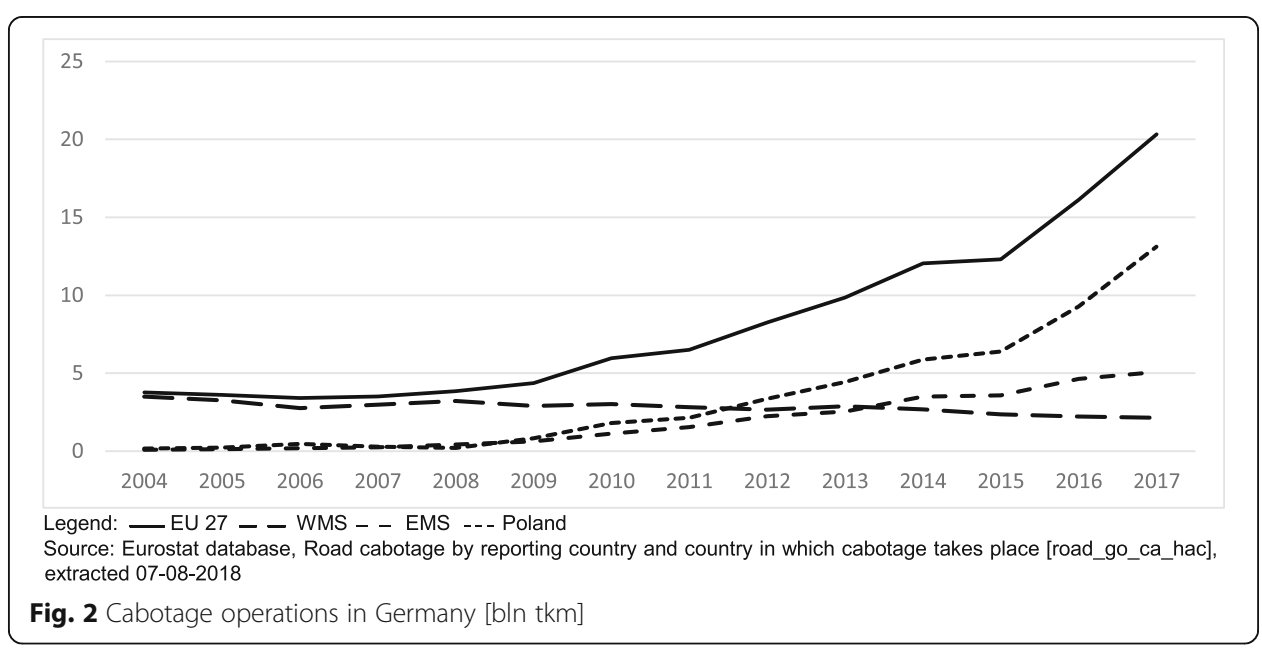




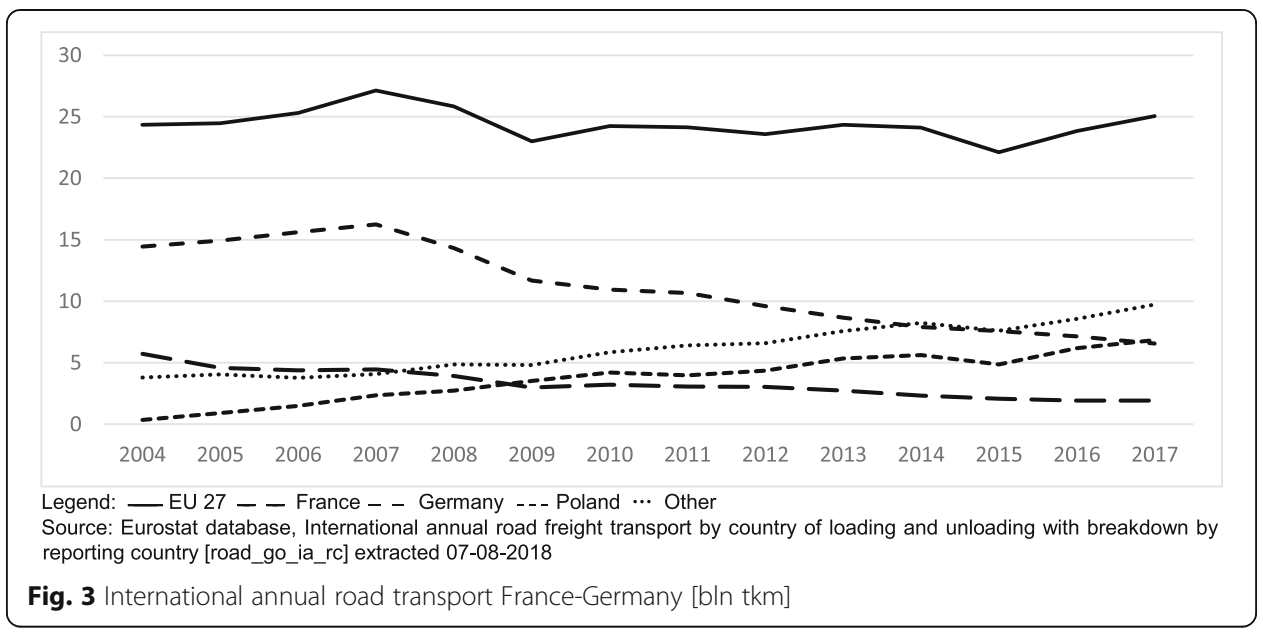

in Germany and France registered trucks can clearly be identified. The share of the cross-trade conducted with in Poland registered trucks surpassed the share of the in France registered trucks in 2009. Further, there is a steadily increasing share of cross-trade mainly conducted with trucks registered in Slovakia, Lithuania, and Spain. (Eurostat database (2018b)).

The international road haulage market France-Poland is dominated by in Poland registered trucks by well above $90 \%$.

The cost of the road haulage industry depends very much on the cost for the drivers. Applying the posted workers directive 96/71/EC means for cabotage operations that the drivers are to be paid at least the minimum wage of the host Member State. Figure 4 displays the minimum wages in Euro per month in 2008 and 2018. (Eurostat database (2018a)) the central European countries have a much higher wage level, compared with the Eastern European countries but also compared with western Member States as Portugal and Spain. Further, it can be seen that even though the growth rate of the minimum wage is substantially higher in the Eastern European countries, the significant difference in wage levels remains between 2008 and 2018.

According to the empirically based model of the Federal Association of Road Haulage, Logistics and Disposal (BGL (2019)) the costs of drivers account for around 31\% of

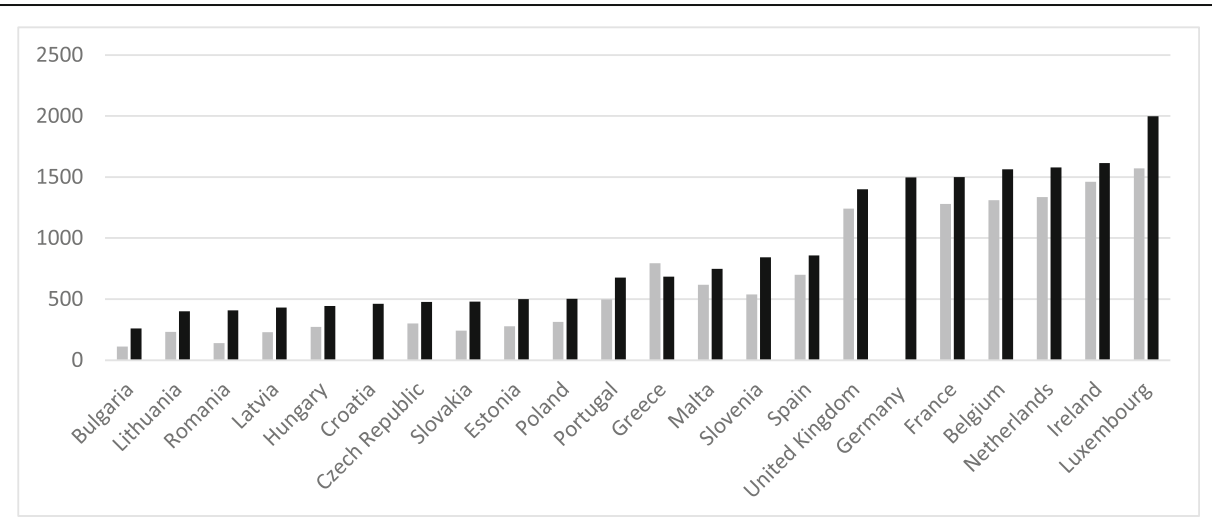

Legend: grey bars 2008 black bars 2018

Source: Eurostat database, Monthly minimum wages - bi-annual data [earn_mw_cur] extracted 11-08-2018

Fig. 4 Minimum wages in European Countries 2008 and 2018 [€/month] 
the total costs in the long distance haulage. The expenses account for another 3\% of the total costs. The framework collective wage agreement between the unified service sector union ver.di and the associations of employers in transport in North-Rhine Westphalia mentions around $13 € /$ h hourly wages for drivers in 2019, increasing through the years until 2021, which is well above the hourly minimum wage of 9.19 $€ / h$ (Ministerium für Arbeit, Gesundheit und Soziales des Landes Nordrhein-Westfalen (2019)). Though the monthly salary can vary substantially between different groups of drivers related to their work experience and special qualifications needed for example for the transport of dangerous goods. The salary data base of ERI (Economic Research Insitute (2019a)) mentiones entry level salaries of 28,592 $€ /$ year up to $47,352 € /$ year for very experienced drivers, on average 38,820 €/year. For Poland (Economic Research Insitute (2019b)) the same database mentiones entry salaries of $11,576 € /$ year up to 14 , $124 € /$ year, on average $11,576 € /$ year. This relates to an hourly salary of $5.46 €$ /hour which is well above the minimum wage in Poland but still less than the minimum wage in Germany. According to the income-related expenses for tax return in Germany the daily expenses are $5 € /$ night if the driver spends the night in the vehicle. The costs for a hotel for a (reduced) weekly rest period are $20 € /$ night. The expenses for a 24-h period are $24 €$. Adding this to the minimum wage in Germany the costs of drivers from Poland would still be lower compared with the wage and expenses of a driver in Germany returning home on a daily basis.

The Figs. 1, 2, 3 show that the notion of the round trip model seems to be applied to quite an extend. Further, it can be assumed, that the extended round trip model is also increasingly applied. This is all conducted based on the existing legislation.

Allowing for unlimited cabotage within 5 days after the incoming international operation will ease the administration of documentation and control which means less cost to the companies and less control cost to the administration. This means cabotage operations on shorter distances become profitable. That provides opportunities for more cabotage operations. Further, extending the period of scheduling of the weekly rest periods to 4 weeks and allowing for two subsequent reduced weekly rest periods make it easier to extend the above mentioned continuous cabotage operation up to this extended period.

\section{International transport}

A second approach to analyse the economic consequences of the proposals of the EU Commission for a new regulation of the European road haulage market is based on a multi-manning round trip model based on the existing regulation as a reference. Two drivers allow for $18 \mathrm{~h}$ continuous driving. With on average $60 \mathrm{~km} / \mathrm{h}$ this means a distance of more than $1000 \mathrm{~km}$. Further, a best case scenario is assumed which means that the drivers can unload and load at the same place within $2 \mathrm{~h}$.

The origin of the round trip is Vilnius where the truck is loaded on Monday from 11 am until $12 \mathrm{am}$ for an international transport operation to Berlin. After $1000 \mathrm{~km}$ the drivers arrive at their destination at Tuesday $6 \mathrm{am}$. After unloading and loading they take their daily rest of $9 \mathrm{~h}$. At $5 \mathrm{pm}$ they are heading for Rotterdam. For $700 \mathrm{~km}$ it needs $12 \mathrm{~h}$ of driving. The two drivers arrive at their destination on Wednesday at $6 \mathrm{am}$. Unloading and loading takes until $8 \mathrm{am}$. They leave Rotterdam for Paris. For the 
distance of $450 \mathrm{~km}$ they need until Thursday 6 am due to the daily rest. After unloading and loading they continue for Madrid at 8 am which requires $22 \mathrm{~h}$ of driving. The truck is unloaded on Friday at $3 \mathrm{pm}$. At $5 \mathrm{pm}$ the drivers leave for Lisbon where they arrive in the middle of the Saturday night. After their daily rest they can unload at $1 \mathrm{pm}$ and leave Lisbon at $3 \mathrm{pm}$ with a payload for Brussels. While on transit through Spain they have a reduced weekly rest period. They continue the journey on Monday morning, take a daily rest time while on transit through France and arrive in Brussels at $6 \mathrm{pm}$. From there they are heading for Salzburg where they arrive after $16 \mathrm{~h}$ of driving and a daily rest period at Wednesday night. The next payload is delivered in Warsaw after 13 $h$ of driving on Thursday noon. After unloading and loading they take their daily rest period and leave for Vilnius as the last destination of this round trip. They arrive there on Friday at $7 \mathrm{am}$. After unloading they take their weekly rest period before they start another round trip on Monday morning.

The driving time of each driver during these 2 weeks is $71 \mathrm{~h}$ which is well below the maximum of $90 \mathrm{~h}$. Further, this round trip is scheduled with less than 3 days in the host Member States of the international transport operations. The weekly rest period is taken while on transit in Spain. Since in reality unloading and loading won't be at the same place it seems plausible that the round trip actually will take more than 2 weeks. Further, there are several countries like Denmark, Italy and Switzerland which weren't on schedule. It seems feasible to extend the round trip up to 3 weeks. A time period of 4 weeks for scheduling up to two reduced weekly rest periods will certainly allow to organise a round trip while staying underneath the time threshold of 3 days in the host Member States and, therefore, to avoid to apply the minimum wage regulations of the host Member States.

\section{Political debate}

\section{Discussion of the proposals in the committee on transport and tourism}

The Committee of Transport and Tourism has been in charge to draft reports on the three legislative proposals of the European Commission amending Regulation (EC) No 1072/2009, Regulation (EC) 561/2006, and Directive 2006/22/EC.

With respect to Regulation (EC) No 1072/2009 the commission proposed to alter the cabotage regulation from 3 cabotage operations within 7 days after an incoming international operation to an unlimited number of cabotage operations within 5 days after an incoming international operation. In the draft report the rapporteur suggested an unlimited number of cabotage operations within $48 \mathrm{~h}$ after the incoming international operation from a haulier's Member State of establishment. (Committee of Transport and Tourism (2017b)).

There have been a variety of amendments (Committee of Transport and Tourism (2018b)) suggested for this regulation in the draft report. They are displayed in Table 1 as following: $\mathrm{x}$ days for cabotage operations in $\mathrm{y}$ days after an incoming international operation / days of no further cabotage in that host Member State. Further, a * indicates a 'return to country of registration'-clause.

Members of the political groups of the central European Member States tend to suggest a rather restrictive regulation of cabotage operations. They favour an unlimited number of cabotage operations following an incoming international transport operation 
Table 1 Amendments regarding the restriction of days of cabotage

\begin{tabular}{|c|c|c|c|c|c|c|c|c|}
\hline \multirow[t]{3}{*}{ Member State } & \multicolumn{8}{|c|}{ Amendments by members of } \\
\hline & EPP & $S \& D$ & ECR & ALDE & Verts/ ALE & GUE-NGL & EFDD & ENF \\
\hline & \multicolumn{8}{|c|}{$\begin{array}{l}\text { X cab. Operations in y days after an intern. op. / days of no cab. op. in the same host } \\
\text { Member State }\end{array}$} \\
\hline Netherlands & & & & & 2 in $1 / 21$ & & & \\
\hline Germany & $\mathrm{X}$ in $2 / 5^{*}$ & 2 in $2 / 7^{*}$ & & & & & & \\
\hline Belgium & $X$ in $5 / 7$ & 2 in $2 / 7^{*}$ & $X$ in 3 & & & & & \\
\hline France & 1 in $3 / 7$ & 2 in $2 / 7^{*}$ & & $X$ in $2 / 7$ & 2 in $1 / 21$ & & & $X$ in 2 \\
\hline Luxembourg & $X$ in $3 / 14$ & & & & & & & \\
\hline Austria & 3 in 5 & 2 in $2 / 7^{*}$ & & & & & & \\
\hline Italy & & 1 in $1 / 7^{*}$ & & & & & $X$ in $3 /^{*}$ & \\
\hline United Kingdom & & 2 in $2 / 7^{*}$ & 3 in 7 & & & & & \\
\hline Finland & & & & & & $X$ in $5 / 8$ & & \\
\hline Sweden & $X$ in $5 / 10$ & & $\perp^{*}$ & & & & & \\
\hline Spain & & $X$ in 5 & & 3 in 5 & & & & \\
\hline Portugal & $X$ in 5 & $X$ in 7 & & 3 in $7 / 7$ & & & & \\
\hline Poland & $X$ in $7 / 2$ & $X$ in 7 & $X$ in 7 & & & & & \\
\hline Czech Republic I & & & $X$ in 7 & 3 in $7 / 7$ & & & & \\
\hline Czech Republic II & & & & $X$ in $7 /^{*}$ & & & & \\
\hline Slovakia & & & $X$ in 7 & & & & & \\
\hline Hungary & $X$ in 7 & & & & & & & \\
\hline Croatia & & & & $\mathrm{X}$ in $7 /^{*}$ & & & & \\
\hline Latvia & & & $X$ in 7 & & & & & \\
\hline Bulgaria & $X$ in $Y$ & & $X$ in 7 & & & & & \\
\hline Romania & $X$ in $Y$ & $X$ in 10 & & & & & & \\
\hline
\end{tabular}

within a small number of days as well as a period of no further cabotage operations in that host Member State. The Socialists \& Democrats even limit the number of cabotage operations within one or 2 days following an incoming international transport operations, suggest a 7 day period of no further cabotage operation in that host Member State and add a return clause to the state of registration. The Green / ALE do not suggest a return clause but extend the period of no further cabotage operation to 3 weeks.

The committee members of the western European Member States at the fringe of Europe tend to suggest unlimited cabotage operations within 5 to 10 days and no return clause. Members of the eastern European Member States suggest unlimited cabotage operations mostly within 7 days after an incoming international transport operation and almost all without a return clause. Members of the furthest Member States Bulgaria and Romania suggest even unlimited cabotage operations within an unlimited number of days following an international transport operation.

With respect to Regulation (EC) 561/2006 the European Commission proposed to alter the period for arranging weekly rest periods from two to 4 weeks. So far drivers can have one reduced weekly rest period within the 2 weeks and have to compensate for this in combination with a following regular weekly rest period. With the suggested regulation they can have up to two consecutive reduced rest periods as long as there is a compensation en bloc with the following weekly rest period. In the draft report the 
rapporteur suggested a 4 week period for arranging weekly rest periods and up to 2 consecutive reduced weekly rest periods. Any compensation of reduced weekly rest periods shall be attached to another rest period of at least $24 \mathrm{~h}$. The regular weekly rest periods, reduced weekly rest periods, and any weekly rest periods of more than $45 \mathrm{~h}$ taken in compensation for previous reduced weekly rest periods shall not be taken in a vehicle. They shall be taken in a suitable accommodation, with adequate sleeping and sanitary facilities. Though, this does not apply when the rest period is taken in dedicated areas, the vehicle is stationary and has suitable sleeping facilities for each driver. (Committee of Transport and Tourism (2017a)).

There have been a variety of amendments (Committee of Transport and Tourism (2018a)) suggested for this regulation in the draft report. They are displayed in Table 2 as following: period of scheduling / subsequent reduced weekly rest periods / compensation within 3 or 4 weeks or flexible in combination with a 9 h-, 24 h- or 45 h-rest.

There are quite a few amendments suggesting to keep the existing regulation indicated by the bold figures in the table. Most of these amendments stem from members of political groups of the central European Member States. Within the European Peoples Party members of Germany and Belgium suggested more flexible solutions, especially in terms of a flexible compensation for reduced weekly rest periods whereas

Table 2 Amendments regarding the schedule of reduced weekly rest periods

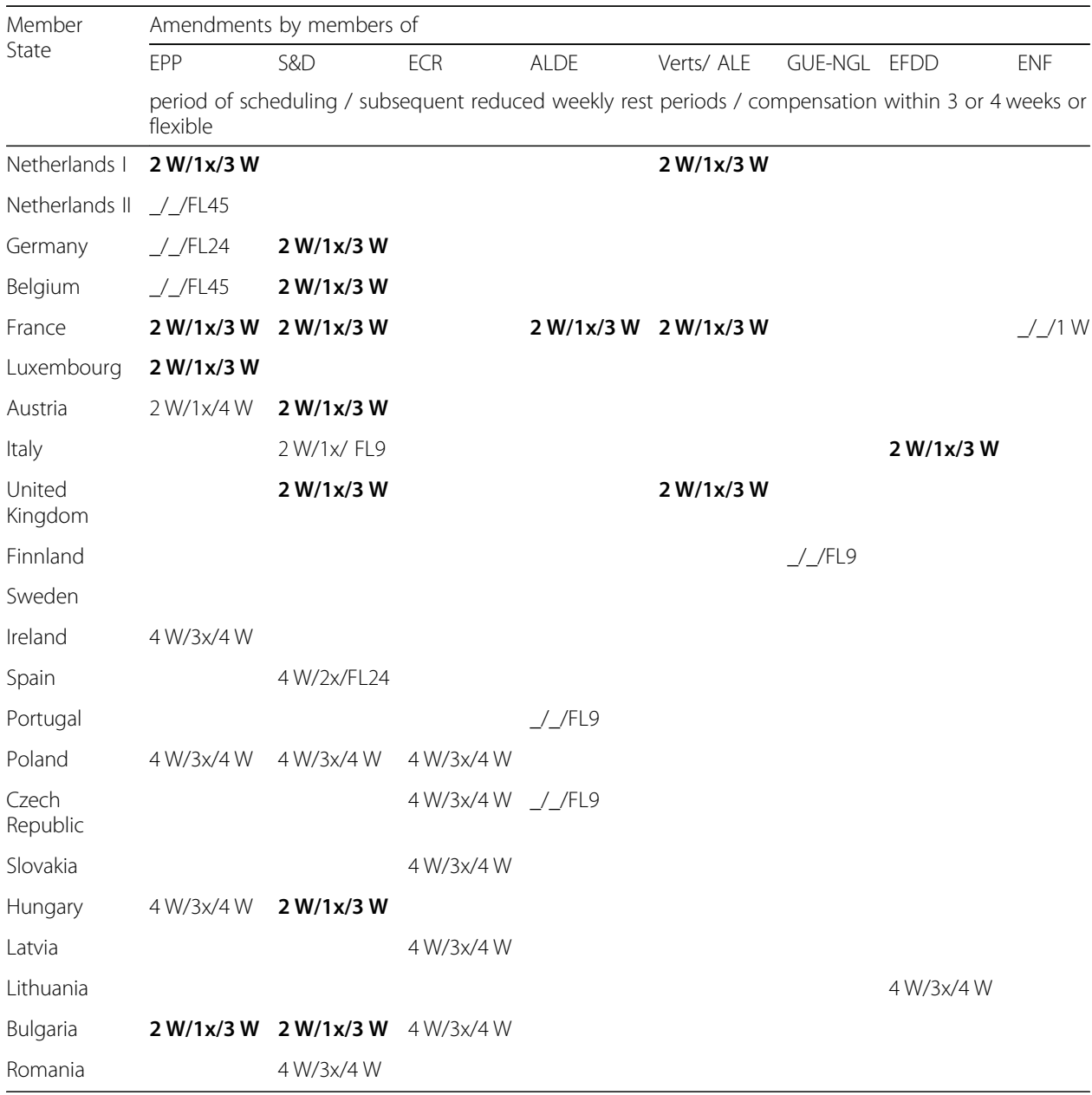

Bold characters: existing regulation 
within the Socialists \& Democrats members seem to be in favour of the existing regulation.

Members of western Member States at the fringe of Europe suggest more flexible solutions for the schedule of weekly rest periods compared with the draft report. Most amendments of members of the eastern Member States also suggest more flexible solutions, especially the opportunity of 3 subsequent reduced weekly rest periods.

Regarding the rest periods another important question discussed is where these times are to be spent. The regulation so far allows to spend the reduced weekly rest periods in the vehicle. The proposal of the Commission only mentions regular weekly rest periods and extended weekly rest periods to be spent in hotels. The draft report of the rapporteur refers to dedicated areas for all weekly rest periods.

Almost all members of political groups of eastern European Member States formulated amendments in favour of spending the reduced weekly rest period in the vehicle and regular weekly rest periods and extended rest periods in so-called dedicated areas. Members of the Socialists \& Democrats of the central European Member States formulated amendments that drivers should spend reduced as well as regular and extended weekly rest periods in a Hotel or in dedicated areas.

With respect to Directive 2006/22/EC the major question seems to be the application of the posted workers directive, Directive 96/71/EC, Article 3, paragraph 1 (b) minimum wage and (c) annual payed leave. The Commission proposed not to apply points (b) and (c) to drivers in the road transport sector employed by undertakings referred to in Article 1, paragraph 3 point (a) of that Directive, when performing international carriage operations as defined by Regulation 1072/2009 and the period of posting is shorter than or equal to 3 days during a period of one calendar month. When the period of posting is longer than 3 days, Member States shall apply points (b) and (c) of the first paragraph of Article 3 of Directive 96/71/EC for the entire period of posting to their territory during the period of that month. The Commission also provides instruments to determine the time spent in the host Member State. The time threshold is meant to ease the administrational burden of the companies conducting international carriage operations in some Member States on an occasional basis. The time threshold does not apply to cabotage operations meaning that minimum paid annual leave and minimum rate of pay of the host Member State apply irrespective of the frequency and duration of the operations carried out by the driver.

In the draft report the rapporteur follows the proposal of the Commission as regards to cabotage operations. In terms of international operations there is no amendment to the proposal of the 3 day-limit but announced to be made at a later stage. (Committee of Transport and Tourism (2017c)).

There have been a variety of amendments (Committee of Transport and Tourism (2018c)) for the application of the posted workers directive made by members of the various political groups of different Member States. They are displayed in Table 3 as following: application for international transport operation / transit operation / cabotage operation. Figures display the time threshold as from which the posted workers shall be applied.

Almost all amendments are not in favour of the application of the minimum wage and paid annual leave regulation to the road haulage sector for transit operations or they do not mention it. 
Table 3 Amendments regarding the application of the Posting of Workers Directive

\begin{tabular}{|c|c|c|c|c|c|c|c|c|}
\hline & \multicolumn{8}{|c|}{ Amendments by members of } \\
\hline & $\overline{\mathrm{EPP}}$ & $S \& D$ & ECR & ALDE & Verts/ ALE & GUE-NGL & EFDD & ENF \\
\hline & \multicolumn{8}{|c|}{ international transport / transit / cabotage } \\
\hline Netherlands & $5 / \mathrm{no} /$ & & & no/no/yes & yes/_yes & & & \\
\hline Germany I & 3/no/_ & yes/_/yes & & & & & & \\
\hline Germany ॥ & & no*/yes/yes & & & & & & \\
\hline Belgium & & yes/_/yes & & & & & & \\
\hline France & yes/_yes & yes/_/ yes & & & yes/_yes & & & $3 /$ \\
\hline Luxembourg & yes/_/yes & & & & & & & \\
\hline Austria & & yes/_/yes & & & & & & \\
\hline Italy & & yes/_/_ & & & & & yes/3/yes & \\
\hline Denmark & & & & $n 0^{*}, 4 / \_/ 4$ & & & & \\
\hline $\begin{array}{l}\text { United } \\
\text { Kingdom }\end{array}$ & & yes/_yes & & & & & & \\
\hline Finnland & & & & & & no/_/_ & & \\
\hline Sweden & & & & & & & & \\
\hline Ireland & no/no/8 & & & & & & & \\
\hline Spain & 6/_/6 & $8 / \mathrm{no} / 6$ & & _/no/_ & & & & \\
\hline Portugal & 10/no/6 & no/no/8 & & & & & & \\
\hline Poland & no/no/8 & 8/_/_ & $11 /$ no/8 & & & & & \\
\hline Hungary & no/no/8 & & & $13 /$ no/8 & & & & \\
\hline $\begin{array}{l}\text { Czech } \\
\text { Republic I }\end{array}$ & & 8/_/_ & 11/no/8 & no/no/yes & & & & \\
\hline $\begin{array}{l}\text { Czech } \\
\text { Republic II }\end{array}$ & & & & $n 0^{*}, 4 / \_/ 4$ & & & & \\
\hline Slovakia & & & 11/no/8 & & & & & \\
\hline Latvia & & & 11/no/8 & & & & & \\
\hline Lithuania & & & & & & & no/no/_ & \\
\hline Bulgaria I & 13/no/8 & 13/no/8 & 11/no/8 & 13/no/8 & & & 13/no/8 & \\
\hline Bulgaria II & no/no/8 & & & & & & & \\
\hline Romania I & $* * / /$ no & $\begin{array}{l}7 / \mathrm{no} / \mathrm{no} \text {, } \\
\text { if cabotage } \\
\text { is limited }\end{array}$ & & & & & & \\
\hline Romania II & & 17/_/11 & & & & & & \\
\hline
\end{tabular}

For international transport operations most members of political groups in central European Member States seem to be in favour of applying the wage regulations of the posted workers directive, some support a time threshold similar to the proposal of the European Commission. Members of Finland and Ireland are against its application or in favour of a more generous time threshold, like Portugal or Spain. Most members of the political groups of eastern European Member States support a much more generous time threshold before applying the wage regulations of the posted workers directive.

For cabotage operations all amendments of members of the different political groups of the central European Member States are in favour of applying the wage regulations of the posted workers directive as from day one whereas members of different political groups of the fringe western European Member States as well as the eastern Member States are in favour of a time threshold, 8 days in most cases. 


\section{Political process}

The amendments discussed above have been voted upon in the committee and there have been final votes upon the three amended draft reports at 4 June 2018. With respect to Regulation (EC) No 1072/2009 the result of the final vote was 30 votes in favour, 15 against, 3 abstentions. In the report it is proposed that undertakings can conduct cabotage operations subsequent an international carriage on the way back to a haulier's Member State of establishment within 7 days. In the host Member State these cabotage operations have to be conducted within a time limit of $48 \mathrm{~h}$. (Committee of Transport and Tourism (2018e)).

With respect to Regulation (EC) 561/2006 the result of the final vote was 33 votes in favour, 14 against, 3 abstentions. In the report it is proposed to schedule weekly rest periods within a 4 week period and allow for up to two consecutive reduced weekly rest periods. Further, the compensation for reduced weekly rest periods have to be taken in combination with a regular weekly rest period. The rest periods shall not be taken in a vehicle but in a suitable accommodation unless the rest is taken in a dedicated area, the vehicle is stationary and has suitable sleeping facilities for each driver. (Committee of Transport and Tourism (2018d)).

With respect to Directive 2006/22/EC the result of the final vote was 27 in favour, 21 against, 0 abstentions. In the report it is proposed that Member States shall not apply Directive 96/71/EC to drivers in the road transport sector employed by undertakings referred to in Article 1 paragraph 3 point (a) of that Directive, when performing international carriage operations as defined by Regulations (EC) No 1072/2009 and transit operations when a driver transits through a Member State without loading or unloading freight. (Committee of Transport and Tourism (2018f)).

All three reports were submitted to the European Parliament at 7 June 2018. At 14 June 2018 all three requests from the rapporteurs to enter into interinstitutional negotiations were rejected in plenary. At 3 July 2018 there was a controversial debate on all three reports in plenary. At 4 July the plenary voted on the Commission's proposals and the amendments. All three proposals and the amendments were rejected. Therefore, the rapporteurs requested the matter to be referred back to the committee responsible for interinstitutional negotiations. These requests were accepted by the plenary.

\section{Summary and conclusion}

Within the scope of the first Mobility Package proposed in May 2017 three proposals were made by the European Commission in order to amend the regulation of the access to the international road transport market (Regulation (EC) No 1072/2009) and to amend the regulation of the social conditions in the road haulage market. Proposals for the latter refer to Regulation (EC) 561/2006 as regards driving times and rest periods and to Directive 2006/22/EC laying down specific rules especially for the payment of drivers with respect to the posted workers directive (Directive 96/71/EC and Directive 2014/67/EU).

In order to ease the administrational burden the access to international transport and cabotage operations is clarified. As access to international transport operations shall remain free access to cabotage operations shall be limited to unlimited cabotage operations within 5 days subsequent to an international incoming transport operation. Further, two consecutive reduced rest periods within a period of 4 weeks shall provide the transport companies with more flexibility to schedule their transport operations. 
Finally, for international transport operations minimum wages and annual paid leave regulation of a host Member State shall be applied if transport operations exceed a time threshold of 3 days in a month. The wage regulations of the host Member State shall be applied for cabotage operations as from day one.

Potential effects of these proposals on European road transport markets were discussed by means of a round trip with an origin in Poland an international journey to Germany, cabotage operations in Germany, an international journey back to the origin in Poland. This round trip can be extended by linking another international transport operation and subsequent cabotage operations before returning to the origin in Poland. The dominance of the international transport markets Poland-Germany and PolandFrance by trucks registered in Poland can be explained by variations of this round trip as well as the steadily increasing market shares of cabotage conducted with in Poland registered trucks. Unlimited cabotage operations within 5 days after an incoming international transport operation and the opportunity to combine two subsequent reduced weekly rest periods within a 4 week period will act like a further deregulation of the road haulage markets and foster extended round trip solutions. Shorter cabotage trips will become profitable even though it will be clarified that all cabotage operations have to be operated with respect to the minimum wage regulation of the host Member States. Increased productivity would be rather the result of increased cost efficiency due to applying minimum wages in more transport markets of the host Member States than the result of increased technical efficiency due to avoiding empty runs.

The political discussion of these issues has been analysed by means of a content analysis of the amendments of members of different political groups and regions in the responsible Committee of Transport and Tourism. In their amendments members of the different political groups in the central European Member States, the Netherlands, Germany, Belgium, Luxembourg, France, and Italy, suggested to restrict cabotage operations comparable to the existing regulation. Especially members of the Socialists \& Democrats also suggested return clauses for the vehicles. Further, most members of the different political groups tend to suggest to keep the 2 week scheduling period including only one reduced rest period which has to be compensated in combination with the following weekly rest period. Finally, they suggest to apply wage regulations according to the posted workers directive for all international and cabotage operations.

The amendments of members of the different political groups of the western European Member States at the fringe of Europe, Finland, Sweden, Ireland, Portugal, and Spain, tend to be more open for the proposals suggested by the European Commission. They are in favour of unlimited cabotage operations within 5 days after an incoming international transport operation and 4 weeks scheduling period including 2 subsequent reduced weekly rest periods. Though, they do not want the wage regulations of the posted workers directive to be applied to international transport operations or at least a much longer time threshold compared with the proposal of the Commission. They also suggest a time threshold for cabotage operations.

The amendments of members of the different political groups of the eastern European Member States are well beyond the scope of the proposals of the Commission. They tend to be in favour of unlimited cabotage operations within 7 and 10 days after an incoming international transport operation and a 4 week scheduling period including even up to 3 reduced weekly rest periods and flexible solutions for compensation of 
the reduced rest periods. Further, they do not want the wage regulations of the posted workers directive to be applied to international transport operations or at least a much longer time threshold compared with the proposal of the Commission. They also suggest a time threshold of 8 days for cabotage operations.

These controversial positions were reflected in the debate of the Parliament at 3 July 2018 which led finally to the rejection of the proposals as well as the amendments. Therefore, the rapporteurs successfully requested the matter to be referred back to the committee responsible. In December 2018 the European Council of Ministers adopted its position on the three mobility package proposals. In April 2019 the European Parliament finally adopted its position on the three proposals. After this first reading the institutions now need to agree on the final texts to be voted on. In September 2019 the members of the Committee of Transport and Tourism committee decided to open interinstitutional negotiations in terms of Regulation (EC) No 1072/2009 (30 in favour, 14 against, 2 abstentions), Regulation (EC) 561/2006 (30 in favour, 15 against, 2 abstentions), and Directive 2006/22/EC (28 votes in favour, 16 against and 3 abstentions) (European Parliament (2019)).

It seems that before the road haulage markets can be further deregulated the preconditions for a fair competition and an improvement of the social working conditions of drivers should be promoted. That is the clear definition of beginning and ending of international transport operations and cabotage operations, a faster penetration of the vehicle fleet with digital tachographs of the latest generation in order to facilitate a better enforcement of many of the regulations, and the definition, certification, and financing of dedicated areas, which shall allow the drivers to spend reduced, regular, and extended weekly rest periods in the vehicle. Since these areas would be easily accessible and provide the drivers with all the facilities they need during their rest periods the flexibility and productivity of the branch as well as the working conditions of the drivers would be supported.

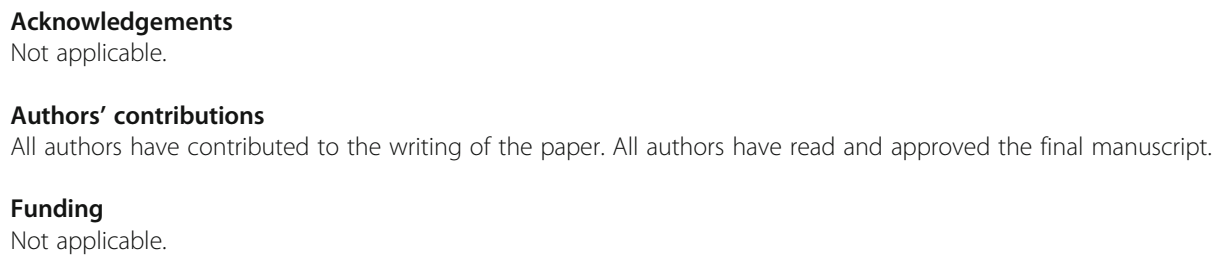


positioning by means of tachographs (COM(2017)0277 - C8-0167/2017-2017/0122(COD)). https://www.europarl.europa. eu/doceo/document/TRAN-PR-615412_EN.pdf. Accessed 17 Mar 2020

Committee on Transport and Tourism (2017b) DRAFT REPORT on the proposal for a regulation of the European Parliament and of the Council amending Regulation (EC) 1071/2009 and Regulation (EC) 1072/2009 with a view to adapting them to developments in the sector (COM(2017)0281 - C8-0169/2017-2017/0123(COD)). https://www.europarl.europa.eu/ doceo/document/TRAN-PR-612273_EN.pdf. Accessed 17 Mar 2020

Committee on Transport and Tourism (2017c) DRAFT REPORT on the proposal for a directive of the European Parliament and of the Council amending Directive 2006/22/EC as regards enforcement requirements and laying down specific rules with respect to Directive 96/71/EC and Directive 2014/67/EU for posting drivers in the road transport sector (COM(2017)0278 - C8-0170/2017-2017/0121(COD)). https://www.europarl.europa.eu/doceo/document/TRAN-PR-615504_EN.pdf. Accessed 17 Mar 2020

Committee on Transport and Tourism (2018a) AMENDMENTS 236-494, Draft report, Wim van de Camp, amending Regulation (EC) No 561/2006 as regards on minimum requirements on maximum daily and weekly driving times, minimum breaks and daily and weekly rest periods and Regulation (EU) 165/2014 as regards positioning by means of tachographs (COM(2017)0277 - C8-0167/2017-2017/0122(COD)). https://www.europarl.europa.eu/doceo/document/ TRAN-AM-618309_EN.pdf. Accessed 17 Mar 2020

Committee on Transport and Tourism (2018b) AMENDMENTS 245-445, Draft report, Jens Nilsson, amending Regulation (EC) No 1071/2009 and Regulation (EC) No 1072/2009 with a view to adapting them to developments in the sector, Proposal for a regulation (COM(2017)0281 - C8-0169/2017-2017/0123(COD)). https://www.europarl.europa.eu/doceo/document/ TRAN-AM-618216_EN.pdf. Accessed 17 Mar 2020

Committee on Transport and Tourism (2018c) AMENDMENTS 253-595, Draft report, Merja Kyllönen, Enforcement requirements and specific rules for posting drivers in the road transport sector (COM(2017)0278 - C8-0170/2017-2017/ 0121(COD)). https://www.europarl.europa.eu/doceo/document/TRAN-AM-618251_EN.pdf. Accessed 17 Mar 2020

Committee on Transport and Tourism (2018d) REPORT on the proposal for a regulation of the European Parliament and of the Council amending Regulation (EC) No 561/2006 as regards on minimum requirements on maximum daily and weekly driving times, minimum breaks and daily and weekly rest periods and Regulation (EU) 165/2014 as regards positioning by means of tachographs (COM(2017)0277 - C8-0167/2017-2017/0122(COD)). https://www.europarl.europa. eu/doceo/document/A-8-2018-0205_EN.pdf. Accessed 17 Mar 2020

Committee on Transport and Tourism (2018e) REPORT on the proposal for a regulation of the European Parliament and of the Council amending Regulation (EC) 1071/2009 and Regulation (EC) 1072/2009 with a view to adapting them to developments in the sector (COM(2017)0281 - C8-0169/2017-2017/0123(COD). https:/www.europarl.europa.eu/doceo/ document/A-8-2018-0204_EN.pdf. Accessed 17 Mar 2020

Committee on Transport and Tourism (2018f) REPORT on the proposal for a directive of the European Parliament and of the Council amending Directive 2006/22/EC as regards enforcement requirements and laying down specific rules with respect to Directive 96/71/EC and Directive 2014/67/EU for posting drivers in the road transport sector (COM(2017)0278 - C8-0170/2017-2017/0121(COD)). https://www.europarl.europa.eu/doceo/document/A-8-2018-0206_EN.pdf. Accessed 17 Mar 2020

European Parliament and Council (2002) Directive 2002/85/EC of 5 November 2002 amending Council Directive 92/6/ $577 E E C$ on the installation and use of speed limitation devices for certain categories of motor vehicles in the Community, Official Journal L 327, 04/12/2002, pp. 8 -9. https://eur-lex.europa.eu/eli/dir/2002/85/oj. Accessed 24 Feb 2020

Economic Research Insitute (2019a), Heavy truck driver salary, https://www.salaryexpert.com/salary/job/heavy-truck-driver/ germany. Access date 23 Oct 2019

Economic Research Insitute (2019b), Heavy Truck Driver Salary, https://www.salaryexpert.com/salary/job/heavy-truck-driver/ poland. Accessed 23 Oct 2019

European Commission (2014) Report from the commission to the European Parliament and the council, https://eurlexeuropaeu/legal-content/EN/TXT/PDF/?uri=CELEX:52014DC0222\&from=EN, Access date 16 Oct 2019

European Commission (2017a) Proposal for a DIRECTIVE OF THE EUROPEAN PARLIAMENT AND OF THE COUNCIL amending Directive 2006/22/EC as regards enforcement requirements and laying down specific rules with respect to Directive 96 71/EC and Directive 2014/67/EU for posting drivers in the road transport sector COM(2017) 278. https:/www.europarl. europa.eu/RegData/docs_autres_institutions/commission_europeenne/com/2017/0278/COM_COM(2017)0278_EN.pdf. Accessed 17 Mar 2020

European Commission (2017b) Proposal for a REGULATION OF THE EUROPEAN PARLIAMENT AND OF THE COUNCIL amending regulation (EC) no 1071/2009 and regulation (EC) no 1072/2009 with a view to adapting them to developments in THE sector, COM(2017) 281. https://www.europarl.europa.eu/RegData/docs_autres_institutions/ commission_europeenne/com/2017/0281/COM_COM(2017)0281_EN.pdf. Accessed 17 Mar 2020

European Commission (2017c) Proposal for a REGULATION OF THE EUROPEAN PARLIAMENT AND OF THE COUNCIL amending Regulation (EC) No 561/2006 as regards on minimum requirements on maximum daily and weekly driving times, minimum breaks and daily and weekly rest periods and Regulation (EU) 165/2014 as regards positioning by means of tachographs, COM(2017) 277. https://www.europarl.europa.eu/RegData/docs_autres_institutions/commission_ europeenne/com/2017/0277/COM_COM(2017)0277_EN.pdf. Accessed 17 Mar 2020

European Parliament (2019), Mobility package: MEPs ready to negotiate with council, press releases 24 Sept 2019, https:// www.europal.europa.eu/news/en/press-room/20190923IPR61757/mobility-package-meps-ready-to-negotiate-with-council. Accessed 26 Oct 2019

Eurostat (2018a) Eurostat database, Monthly minimum wages - bi-annual data [earn_mw_cur]. Accessed 11 Aug 2018

Eurostat (2018b) Eurostat database, International annual road freight transport by country of loading and unloading with breakdown by reporting country [road_go_ia_rc]. Accessed 07 Aug 2018

Eurostat (2018c) Eurostat database, Road cabotage by reporting country and country in which cabotage takes place [road go_ca_hac]. Accessed 07 Aug 2018

INRIX (2018) INRIX Global Traffic Scorecard, https://www.rbb24.de/panorama/beitrag/2018/02/berlin-verkehr-stau-trafficscorecard-inrix-2017.file.html/180206\%20Traffic\%20Scorecard.pdf. Accessed 26 Oct 2019 
Koliousis, I. (2016) Assessing the impact of the latest deregulatory developments in the EU28 transport industry production: a critical review based on empirical data, SPOUDAI - journal of economics and business, Vol. 66, Iss. 1/2, pp. 3-21, http:// hdl.handle.net/10419/169175. Accessed 26 Oct 2019

Ministerium für Arbeit, Gesundheit und Soziales des Landes Nordrhein-Westfalen (2019) Tarifregister Nordrhein-Westfalen, Grundvergütung nach Branchen, http://www.tarifregister.nrw.de/tarifinformationen/grundverguetung_branchen/index. php?show=U3BIZGI0aW9ucy0sIExvZ2IzdGIrLSB1bmQgVHJhbnNwb3J0d2lydHNjaGFmdA. Accessed 26 Oct 2019

Steer, Davies, Gleave (2013) Development and Implementation of EU Road Cabotage, Steer, Davies, Gleave (2013) Development and Implementation of EU Road Cabotage, http://www.europarl.europa.eu/RegData/etudes/etudes/join/2 013/495854/IPOL-TRAN_ET(2013)495854_EN.pdf. Accessed 26 Oct 2019

\section{Publisher's Note}

Springer Nature remains neutral with regard to jurisdictional claims in published maps and institutional affiliations.

Submit your manuscript to a SpringerOpen ${ }^{\circ}$ journal and benefit from:

- Convenient online submission

- Rigorous peer review

- Open access: articles freely available online

- High visibility within the field

- Retaining the copyright to your article 